\title{
AN OVERVIEW OF 10 YEARS OF QUALITATIVE METHODS AT JOURNAL OF INTERNATIONAL BUSINESS STUDIES
}

\author{
UM PANORAMA DE 10 ANOS DE MÉTODOS QUALITATIVOS NO JOURNAL OF \\ INTERNATIONAL BUSINESS STUDIES
}

Recebido em: 08/11/2012 - Aprovado em: 27/01/2013 Avaliado pelo sistema double blind review Editora Científica: Manolita Correia Lima

\section{SÍLVIO LUÍS DE VASCONCELLOS silvio.v@ienh.com.br} INSTITUIÇÃO EVANGÉLICA DE NOVO HAMBURGO

\section{IVAN LAPUENTE GARRIDO \\ JEFFERSON MARLON MONTICELLI \\ YEDA SWIRSKI DE SOUZA \\ CYNTIA VILASBOAS CALIXTO \\ UNIVERSIDADE DO VALE DO RIO DOS SINOS}

\begin{abstract}
This paper aims to present an overview of articles published in the Journal of International Business Studies (JIBs), since 2003 till 20I2. According to Web of Knowledge website, JIBS is the most impacting publication focused in International Business. We analyzed 498 articles in order to select papers built under qualitative basis. We found 65 articles under this premise. Firstly, we analyzed keywords under topics focusing in the entire period (2003-2012). Secondly, we analyzed whole abstracts, focusing in the last five years (2008-2012) Afterwards, we detailed keywords, objectives, strategy of research, object, industry and region where they took place. We concluded that qualitative papers are losing space in JiBs. Last years, quantitative papers are serving more to confirm what we know from other studies. Paradoxically, meanwhile complex institutional environments are gaining evidence in International Business, statistics and calculi are those which have been gaining space. More qualitative studies might provide an enriching strategy for better understanding what is going on in new boundaries of IB, like emerging countries. It is a goal of JIBS to expand qualitative studies; it could represent opportunities to researchers from countries less researched, like Brazil.
\end{abstract}

Keywords: qualitative methods; JIBs; keywords; abstracts; international business.

RESUMO

Este artigo tem como objetivo apresentar uma visão geral de artigos publicados no Journal Of International Business Studies (JIBS), desde 2003 até 2012. De acordo com o sitio Web of Knowledge, o JIBS é a publicação mais impactante focada em Negócios Internacionais. Foram analisados 498 artigos com o intuito de selecionar trabalhos construidos sob a forma qualitativa. Foram encontrados 65 artigos sob essa premissa. Em primeiro lugar, foram analisadas as palavras-chave com foco em todo o período (2003-2012). Em segundo lugar, foram analisados os resumos inteiros, com concentração nos últimos cinco anos (2008-2012). Depois, foram detalhadas as palavras-chave, os objetivos, as estratégias de pesquisa, os objetos, as indústrias e as regiões onde ocorreram os estudos. Concluiu-se que os artigos qualitativos estão perdendo espaço no JIBs. Nos últimos anos, trabalhos quantitativos estão servindo mais para confirmar o que já se sabe a partir de outros estudos. Enquanto complexos ambientes institucionais têm vindo a ganhar evidência em Negócios Internacionais, paradoxalmente, são as estatísticas e cálculos que têm tido seu espaço aumentado. Mais estudos qualitativos poderiam fornecer uma enriquecedora estratégia para melhor compreensão do que está acontecendo em novas fronteiras dos Negócios Internacionais, como nos países emergentes. É um objetivo do JIBS expandir os estudos qualitativos, o que poderia representar oportunidades para pesquisadores de países pouco pesquisados, como o Brasil.

Palavras-chave: métodos quantitativos; palavras-chave; resumos; negócios internacionais. 


\section{INTRODUCTION}

Following the expansion of international trade during last four decades, research in International Business (IB) has spread around. Different and complementary paths were thrilled to support this evolution. Some of them involved economic-rational basis, like product cycle (VERNON, 1966), location (DUNNING, 1980, I988; VERNON, 1966, I979) or transaction costs (ANDERSON; GATIGNON, 1986). Meanwhile other laid closer to behavioral issues relating geographic (JOHANSON; WIEDERSHEIM-PAUL, I975) and psychological distances (JOHANSON; VAHLNE, 1977), involvement (JOHANSON; VAHLNE, 1990), learning (VAHLNE; NORDSTRÖM, I993) or relational learning (JOHANSON; VAHLNE, 2003, 2009). Most of these seminal articles were built over empiric studies to support theoretical advances.

Contributions for IB studies use to come from different sources, as it is an interdisciplinary field. JiBs holds the most impacting factor of the journals in IB. According to the specialized website Web of Knowledge (20I2), JIBS is ranked as impact factor 3.557 (5.245 if considered 5-year ranking). Some of the most cited articles in the field mentioned above were published at JIBS (ANDERSON; GATIGNON, I986; DUNNING, I980, I988; JOHANSON; VAHLNE, I977, 2009). JIBS is aligned to theory improvement and methodological advances as stated at its website (JIBS, 20I2) as a commitment "to publish insightful, innovative and impactful research on international business".

Even the JIBS Statement of Editorial Policy (JIBS, 20I2) states the journal seeks "to publish manuscripts with cutting-edge research that breaks new ground, rather than merely making an incremental contribution to international business studies", there is an interesting point that deserve attention: although JiBs had been founded over a rich legacy of qualitative studies, nowadays "such methods [qualitative research] have been progressively marginalized in our field as quantitative methods have become the norm" (BIRKINSHAW; BRANNEN; TUNG, 2OII).

We developed this study with the aim to contribute on understanding which type of research is following straightly the JIBs Policy addressing real-world phenomena, problems or puzzles thru qualitative investigation 
(JIBS, 20I2). Hence, this study aims to offer an overview over theoreticalempiric studies published on JiBs, since 2003 till 20I2, based on keywords and abstracts published ate JIBS website (JIBS, 20I2). Specifically, we intend to know which themes have been researched in IB thru qualitative methods, associated to the keywords (2003-2012) and abstracts (2008-2012). We counted 498 papers (we didn't consider commentaries, perspectives and research notes). Sixty five articles were clearly qualitative or qualitative-quantitative studies, as Table $\mathrm{I}$.

Table I Articles developed under qualitative methods during last Io years

\begin{tabular}{|c|c|c|c|}
\hline Year & Total of articles & Qualitative methods & Percentage \\
\hline 2003 & 34 & 9 & $27 \%$ \\
\hline 2004 & 29 & 6 & $21 \%$ \\
\hline 2005 & 40 & 6 & $15 \%$ \\
\hline 2006 & 46 & 4 & $9 \%$ \\
\hline 2007 & 59 & 13 & $22 \%$ \\
\hline 2008 & 70 & 6 & $9 \%$ \\
\hline 2009 & 72 & 7 & $10 \%$ \\
\hline 2010 & 62 & 3 & $5 \%$ \\
\hline 2011 & 53 & 9 & $17 \%$ \\
\hline $2012^{*}$ & 33 & 2 & $6 \%$ \\
\hline Total & 498 & 65 & $13 \%$ \\
\hline
\end{tabular}

$\left.{ }^{\star}\right) 2012$ January- November

Source: JIBS (2012) - compiled by authors

It's relevant to note that there was a special issue attempting to a call for qualitative papers in 20II. That occasion, II8 subscriptions were made and merely eight were accepted (BIRKINSHAw; BRANNEN; TUNG, 20II).

The qualitative studies report to different topics. We identified 368 different keywords. After excluding some idiosyncratic keywords, like creolization and otherness (HUNG; LI; BELK, 2007) we categorized them in I3 generic topics: culture, emerging markets, finance/performance, individuality/ entrepreneurship issues, industry, innovation/knowledge, institutions, internationalization process, interrelation issues, methodology, resources/ 
capabilities, strategy and theories. We depicted these generic topics in the next section, excepted internationalization process and methodology. Avoiding redundancies, we took out Internationalization Process because it is the main subject of JiBs. We excluded methodology because it is intrinsic to the objectives of this article. 


\section{GENERIC TOPICS IN INTERNATIONAL QUALITATIVE STUDIES}

We organized this section according to generic topics we grouped the 368 keywords. Albeit it means a generalist categorization, it may help to organize the corpus we researched, as proposed by Bardin (1977).

\section{CULTURE}

Culture has been pointed as keyword in several aspects. Sometimes it refers to organizational culture (BRANNEN; PETERSON, 2009), other times and more often, to national (CAPRAR, 20II; GOULD; GREIN, 2009, for example). While it is referring to organizational aspects, usually it regards to multinational enterprises [MNE] (CAPRAR, 20II; YAGI; KLEINBERG, 20II). Frequently qualitative research is useful for cross-cultural studies (YAGI; KLEINBERG, 20II). In some cases culture is connected to other topics, like knowledge (SHAPIRO; OZANNE; SAATCIOGLU, 2008). In a space dimension, culture is referred as local (MOORE, 2OII), or means distance (GERTSEN; SODERBERG, 2OII).

\section{EMERGING MARKETS}

Qualitative studies are helpful for studying specific markets, mainly emergent markets like India (KHANNA; PALEPU, 2004), Mexico (SIEGEL, 2009) and China (HUNG; LI; BELK, 2007). Specifically, ten studies were performed in China, two in South Korea and India, and one in Mexico. Emerging Markets are investigated as destination of sales (Siegel, 2009) or specific characteristics, like Hung, Li and Belk. (2007). MNE's from emerging markets have been studied by qualitative aspects (SIEGEL, 2009). Some developing countries were also studied once: Chile, Dominican Republic, Guatemala, South Korea and Taiwan.

\section{FINANCE/PERFORMANCE}

Measurements usually are associated to quantitative studies. Surprisingly, performance has been studied by qualitative techniques (CHILD; CHUNG; DAVIES, 2003; CHOI; CHANG-BUm; BEAmish, 2004). Child, Chung and Davies (2003) investigated cross-border investments in China; Choi, Chang-bum, 
and Beamish (2004) studied interorganizacional relationships between MNE's and local firms in Korea and performance they achieved as well. International alliances have been their performance analyzed comparing to cultural differences (SIRMON; LANE, 2004). Financing issues during crisis wereinvestigated by a case study of the Gulf Crisis of 1990 - 1991, examining the behavior of the international oil market during that period (wEINER, 2005).

\section{INDIVIDUALITY/ENTREPRENEURSHIP ISSUES}

The role of individuals, sometimes inside the organizations other times as subjects of entrepreneurship issues have been examined by qualitative studies in JIBs. For example careers in internationalized companies were studies by Bolino (2007) and Lau, Shaffer, and $\mathrm{Au}$ (2007). Also, expatriation is often studies by qualitative methods (BOLINO, 2007; CARRAHER; SULLIVAN; CROCITTO, 2008; LAZAROVA; CERDIN, 2007). Some critical points received attention in a cross-cultural analysis, like cronyism and corruption (KHATRI; TSANG; BEGLEY, 2006) and opportunism (VERBEKE; GREIDANUS, 2009). Entrepreneurship sometimes involves the role of individual as a resource to the organization (JONES; COVIELLO, 2005) or as a mentor of an internationalization action as a node of a network (COVIELLO, 2006). Frequently the entrepreneurship is linked to born-global issues (COVIELLO, 2006; FAN; PHAN, 2007).

\section{INDUSTRY}

Specific industry studies have been performed in qualitative methods. The automotive industry was investigated by Moore (20II). He evaluated crosscultural relationships in the organization, and the interaction of manager and worker perspectives. Lamb, Sandberg, and Liesch (2011) analyzed crosscultural relationships in the organization, the interaction of manager and worker perspectives in small wineries. A longitudinal study in furniture industry was developed by Jonsson and Foss (20II). The service sector was also investigated, like Japanese trading (GOERZEN; MAKINO, 2007), and software industry in India, under governance aspects (KHANNA; PALEPU, 
2004). Wireless and telecommunications in Europe were debated under the scope of the internationalization of research and development (R\&D) activities.

\section{INNOVATION/KNOWLEDGE}

This is a wide range investigation field in JIBS, under qualitative methods. The way as innovation takes place usually is related to knowledge formation or transferring (EAPEN, 20I2, p.244), for instance, concluded that "affect-based ties might motivate foreign firms sufficiently to share information with domestic firms at the search stage, reciprocal benefits and social monitoring conferred by common third-party ties are necessary in the transfer stage". The place where knowledge is generated and how is transferred as also often researched (TIPPMANN; SCOTT; MANGEMATIN, 20I2; MARTIN; SALOMON, 2003). Knowledge and innovation were associated as capabilities in international competition (KNIGHT; CAVUSGIL, 2004). In a broadly range, innovation systems have been investigated in qualitative methods, as Spencer (2003).

\section{INSTITUTIONS}

According to North (1990), institutions are the rules of the game. He considered that institutions may refer to formal and informal aspects. In JiBs it is evident. Formal aspects were in the lens of Jackson and Deeg (2008); informal aspects were present in Tsui-Auch and Mollering (2010). In a provocative perspective paper Ricart, Enright, Ghemawat, Hart, and Khanna (2004) included institutional aspects for understanding the new frontiers to international strategy. Some articles associated institutions to other themes, like resourced-based view (WANG; HONG; KAFOUROs; WRIGHT, 20I2; MEYER; PENG, 2005) Or to path dependency (HUTZSCHENREUTER; PEDERSEN; VOLBERDA, 2007).

\section{INTERRELATION ISSUES}

In this topic we considered behavioral and network issues. We included some subjective characteristics like emotion (LEE; YANG; GRAHAM, 2006), commitment (SIEGEL, 2009) and trust (TSUI-AUCH; MOLLERING, 20IO). Other 
keywords are related social aspects like business $\&$ society (JACKSON; DEEG, 2008) and civil society (TEEGEN; DOH; VACHANI, 2004). Some are related to network issues. Siegel (2009, p.II7I) study used a "quasi-natural experiment from Mexico to examine the conditions under which forming a strategic alliance with a foreign multinational firm is actually a superior mechanism for ensuring good corporate governance".

\section{RESOURCES AND CAPABILITIES}

Firms need resources and capabilities to compete internationally (PENG, 200I). During last ten years resource-based view has been associated to IB studies (KNIGHT; KIM, 2009; CUERVO-CAZURRA; MALONEY; MANRAKHAN, 2007; MEYER; PENG, 2005). Often, organization learning is listed as distinctive resource to conquest new markets (TIPPMANN; SCOTT; MANGEMATIN, 20I2). Some studies reveal how domestic firms learns from foreign organizations by knowledge spillovers (EAPEN, 20I2). Javidan (1998) considered that owning resources is not enough for achieving competences; it's necessary capabilities to arrange them. In fact, capabilities in international strategy is frequently researched, sometimes associated to innovation (KNIGHT; CAVUSGIL, 2004), technology (MARTIN; SALOMON, 2003), in a network perspective (YIU; LAU; BRUTON, 2007) or even in a global wide range (LONDON; HART, 2004).

\section{STRATEGY}

According to Dunning (1980), the decision to turn an organization international is a strategic choice motivated by a sort of aspects, like ownership, localization and internalization. This assumption is often mentioned in IB studies. For instance, Brown, Dev, and Zou (2003) studied how some absorptive capabilities are generated due ownership of hotels abroad. Meyer and Altenborg (2008) studies presented a shared ownership of stated-owned Scandinavian telecom companies were incompatible. Ownership and location were associated to strategic decision making by Filatotchev, Strange, Piesse, and Lien (2007: p.556). They presumed that "the entry mode and location decisions appear to be interrelated, with the parent's equity stake in the affiliate depending inter alia upon the location 
within China, and the favored location depending inter alia upon the equity stake". Often Strategy is related to international market. Verlegh (2007; p.36I) observed that consumer behavior is "biased in their evaluations of domestic products vs. foreign alternatives". Also, Shapiro, Ozanne and Saatcioglu. (2008) observed cultural sensitivity in international business when compared consumers in Netherlands and UsA. Besides those behavioral issues, performance is frequently linked to strategy in international business (CAPAR; KOTABE, 2003; CHOI; CHANG-BUM; BEAMISH, 2004).

\section{THEORIES}

International business is a multidisciplinary field of investigation (PENG; WANG; JIANG, 2008). So, a vast range of theories support researches. Some are grounded in classical economics, like transaction costs (CHEN; LI, 2005; ORR; SCOTT, 2008). Other is co-evolutionary theories (HUTZSCHENREUTER; PEDERSEN; VOLBERDA, 2007) and social influenced theories (HUNG; GU; YIM, 2007; VERLEGH, 2007). Some articles are linked to theories yet under consolidation like network (SUN; MELLAHI; THUN, 20IO) and even multinational corporate theory (MARTIN; SALOMON, 2003). Those three theories have been basing some relevant studies. Institutional theory is adopted by Jackson and Deeg (2008), resource-based view by Knight and Kim (2009). Usually economics is related to some other knowledge area, like sociology (JACKSON; DEEG, 2008) and politics (SIEGEL, 2009). Meyer and Peng (2005) proposed an international business theory based on organizational economics theory, resourcebased theories and institutional theories. Economic reforms in emerging countries have been studied appealing to economics (DEL SOL; KOGAN, 2007). Sometimes, economics is connected to institutional theory (JACKSON; DEEG, 2008) or used to support longitudinal studies like Siegel (2009). 


\section{TRAILS ON ABSTRACTS}

After we grouped keywords in topics, we analyzed other aspects. We designed some further criteria in order to describe which themes have been investigated under qualitative methods. Hence, we included some additional information to this exploratory study, in order to organize comparisons on the final considerations. The categories we chose may highlight important aspects from the articles. Also, it may allow different way of analysis to who is interested in develop qualitative studies in IB as well. The categories are:

A Strategy of investigation: we considered which were stated in the abstracts. We found study cases, ethnography, phenomenography, photo-elicitation, and research over previous registered interviews;

B Object of study: For object of study we refer to the level of analysis. Countries, industries, organizations, networks, individuals, and also publications;

C Place where the research was performed: The place where the research was performed refers to regions and countries, if it were specified on abstracts. We identified studies in China (Io); USA (9); Japan (3); Germany (2); India (2); South Korea (2); Australia (I); Brazil (I); Chile (I); Dominican Republic (I); England (I); Guatemala (I); Israel (I); Italy (I); Mexico (I); Norway (I); Romania (I); Sweden (I); Taiwan (I) and The Netherlands (I). Some studies refer to continents or part of them. Europe (2); Asia (I); Asian Pacific Rim (I); Central Europe (I); and East Europe (I);

D Objectives: we looked for objectives in all abstracts. It's relevant to understand why authors decide for qualitative methods. In order to avoid an extent table of information we concentrated analysis in last five years (2008-2012). 


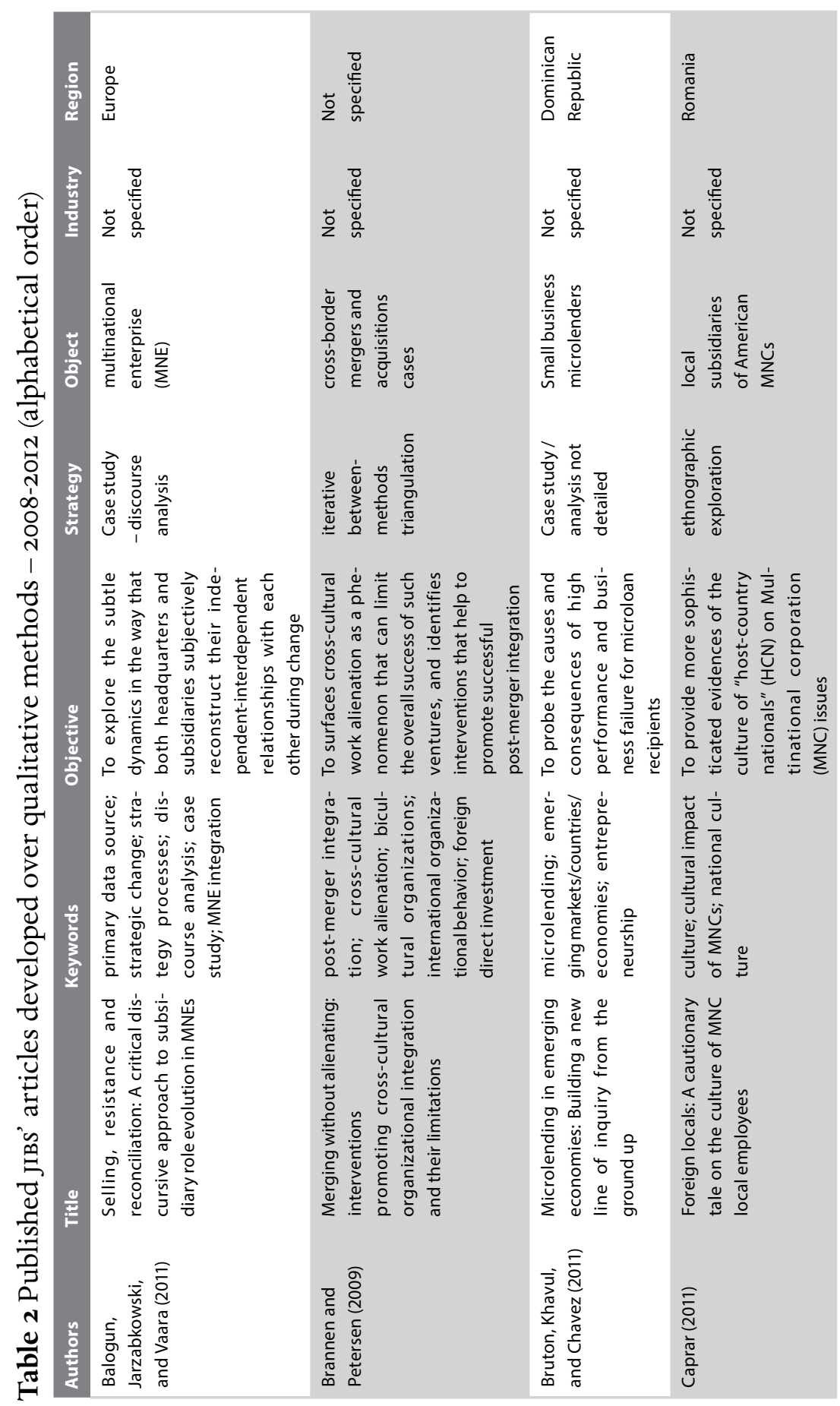




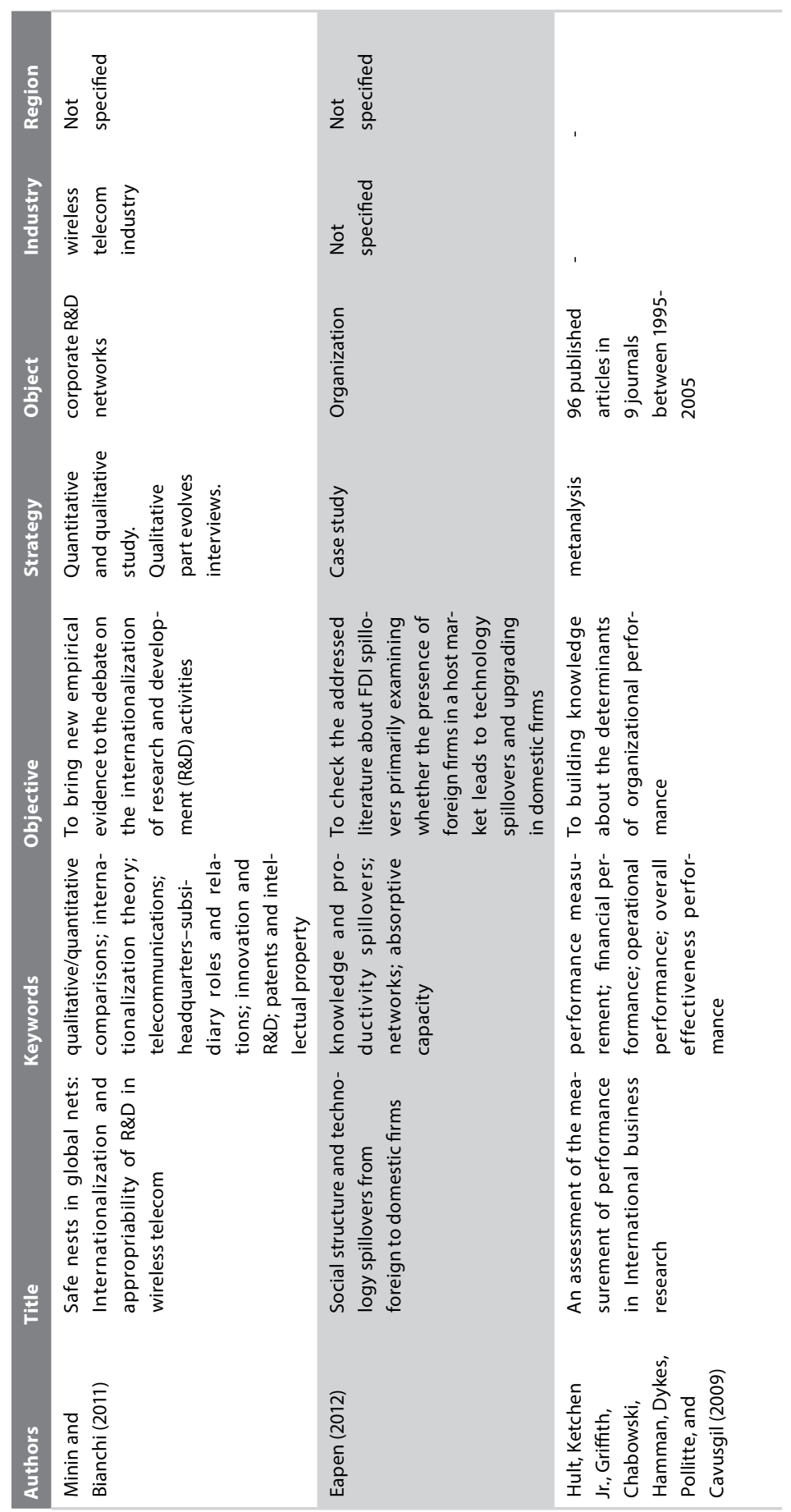




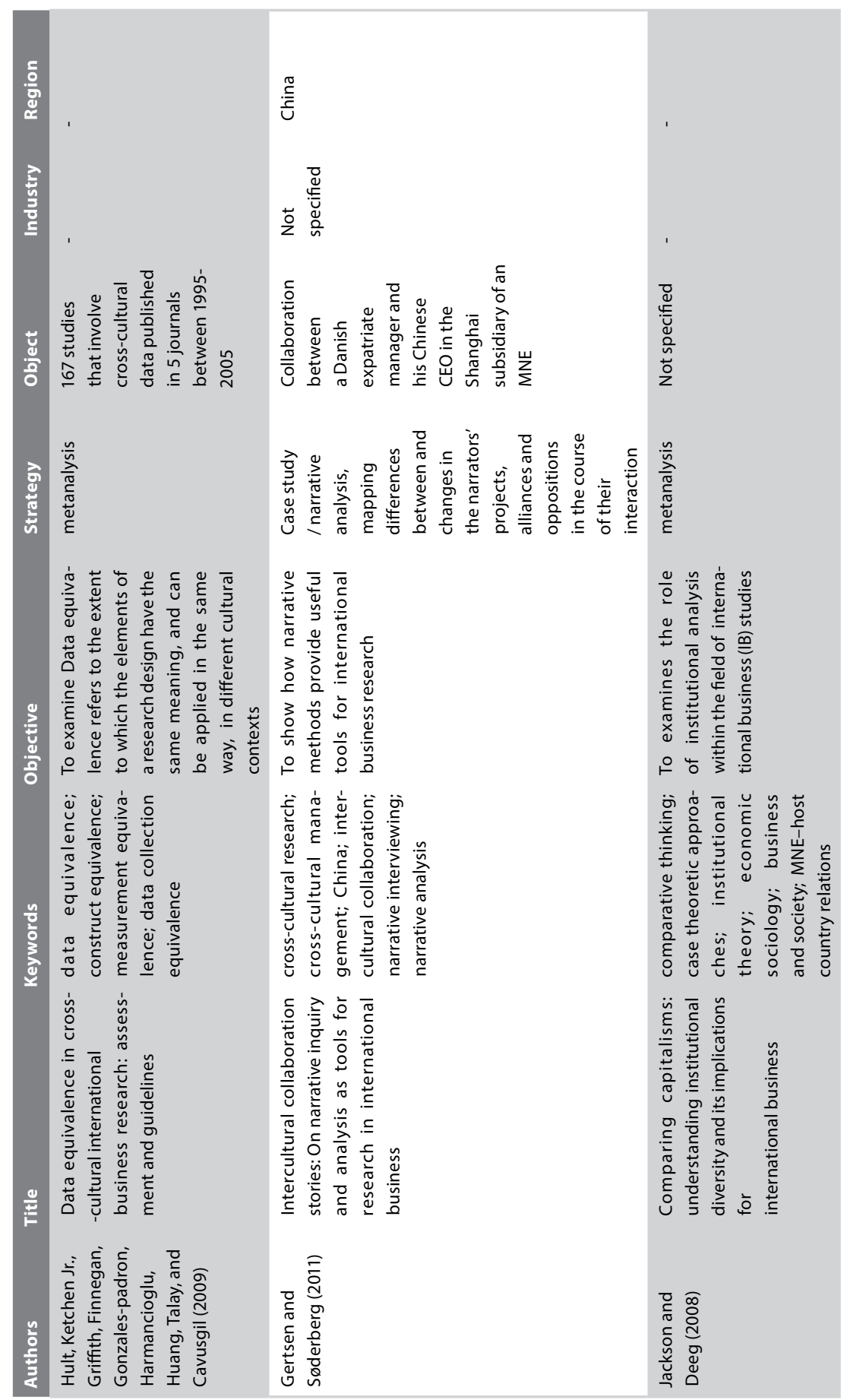




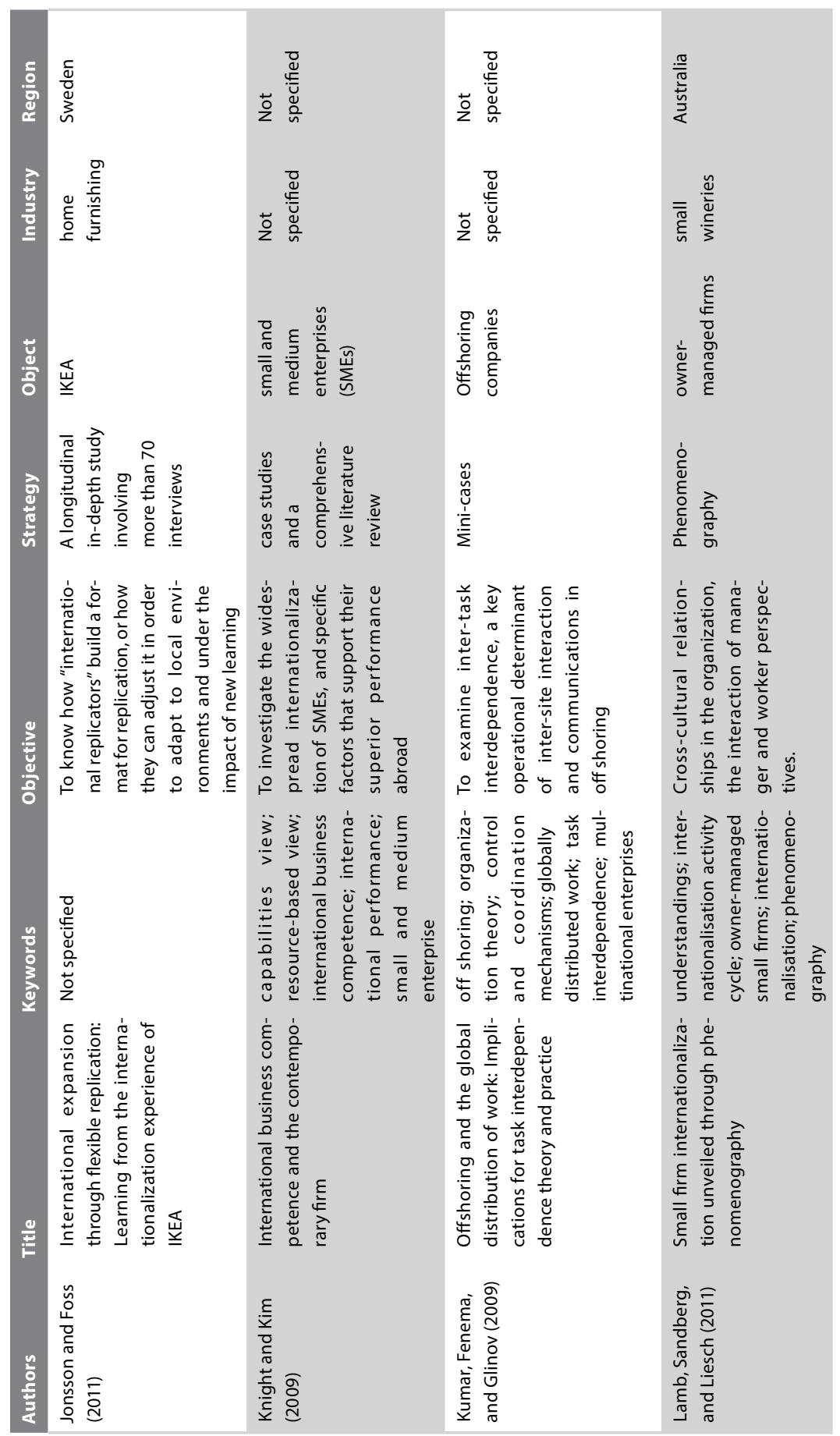




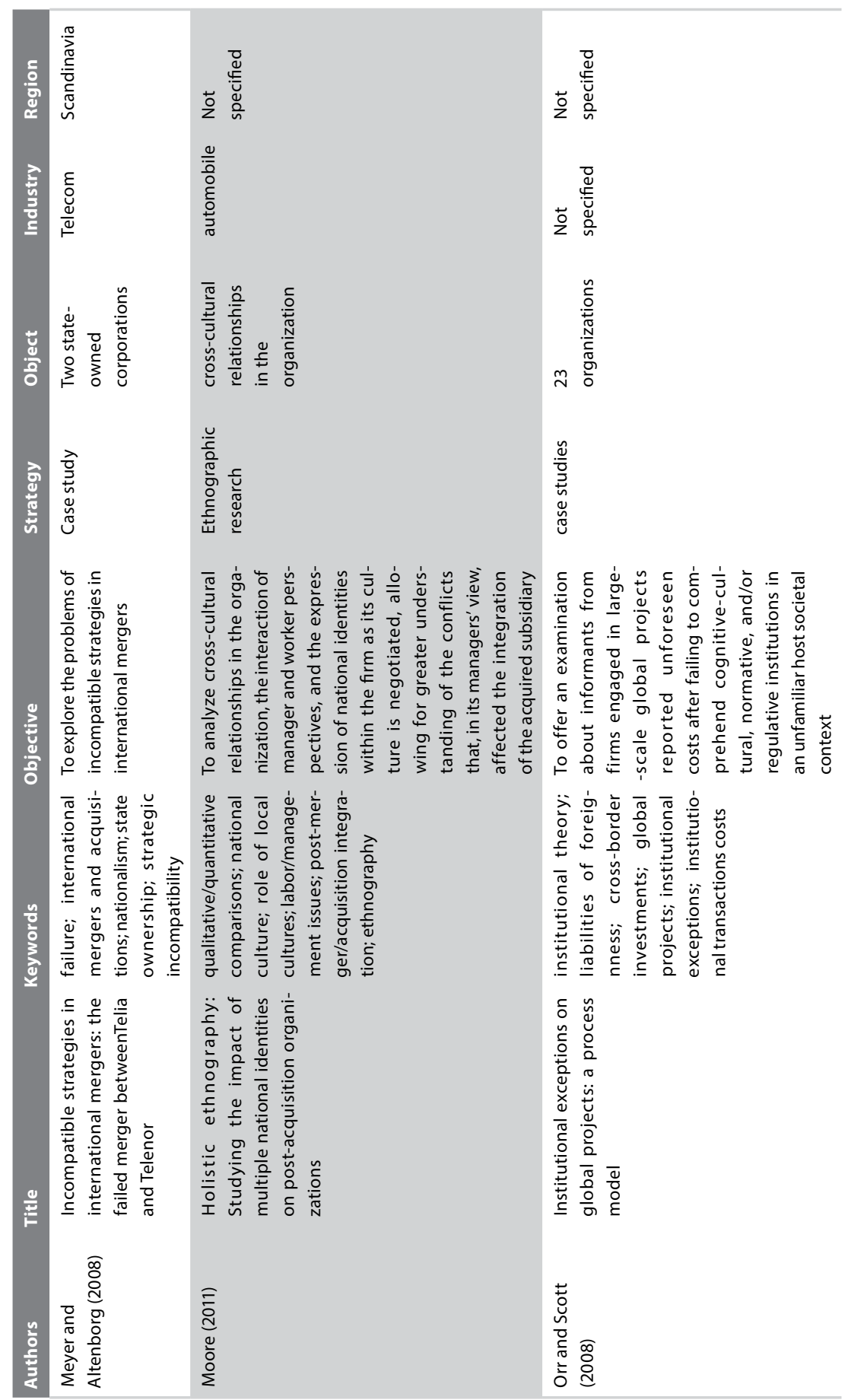




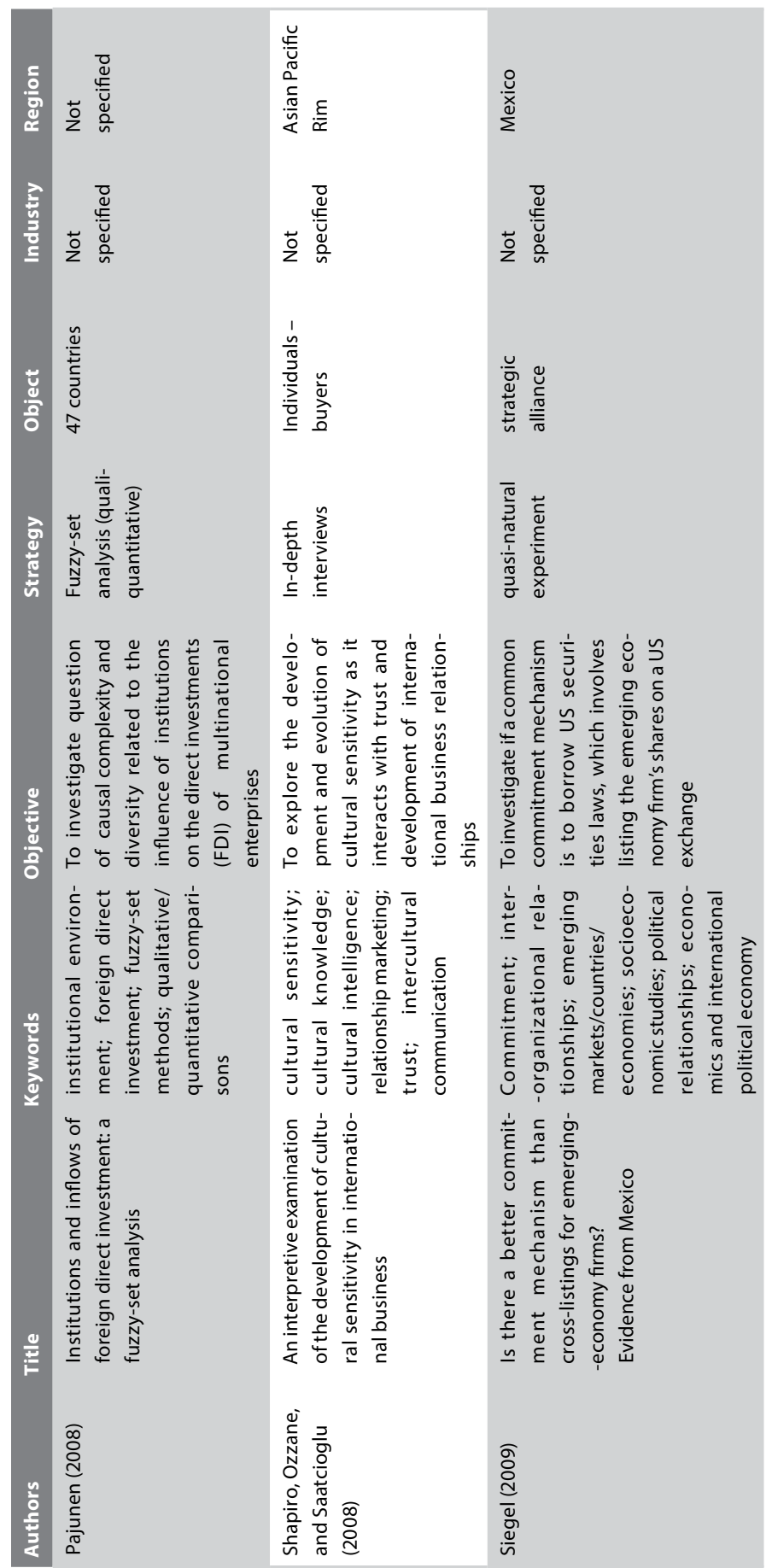




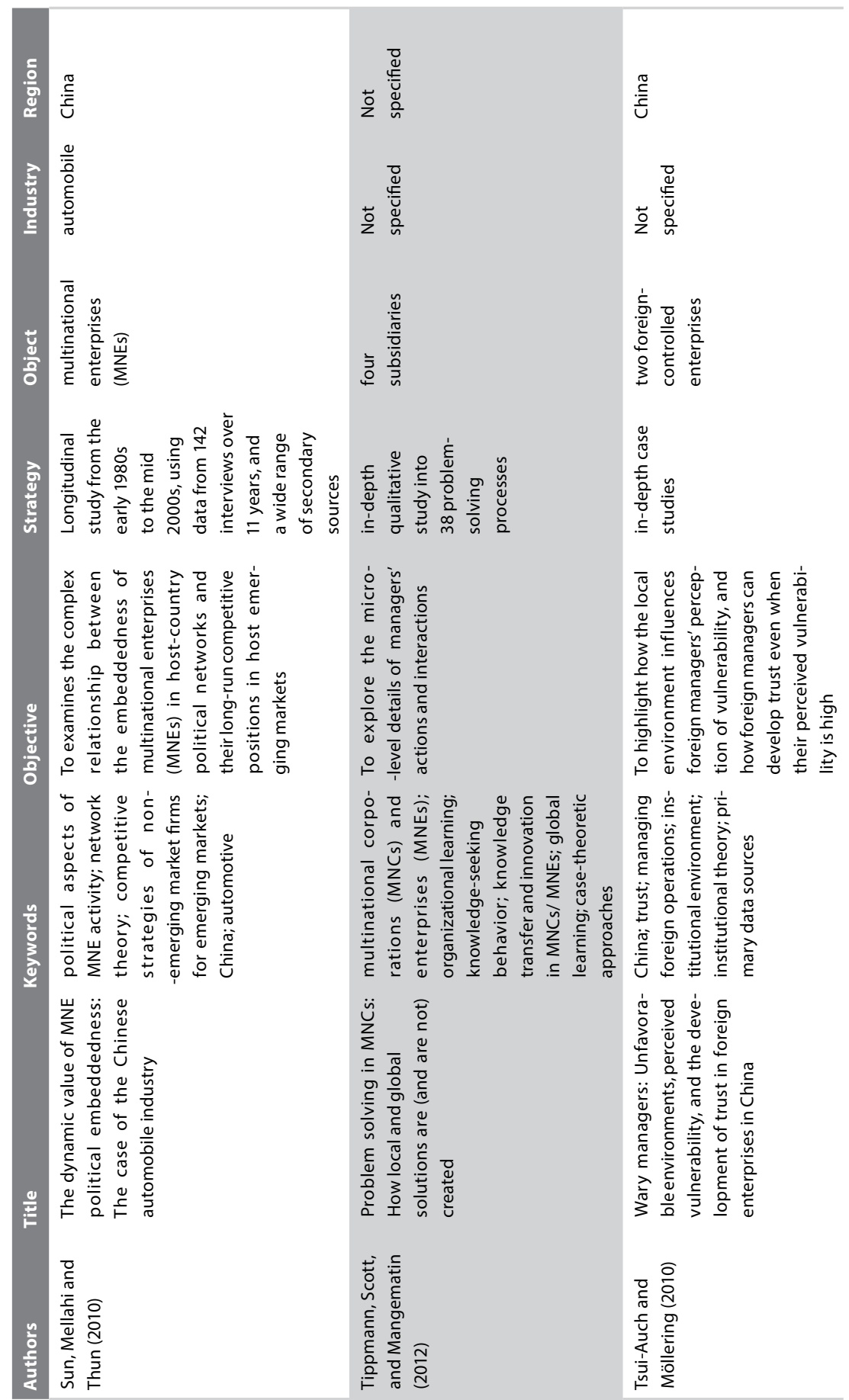




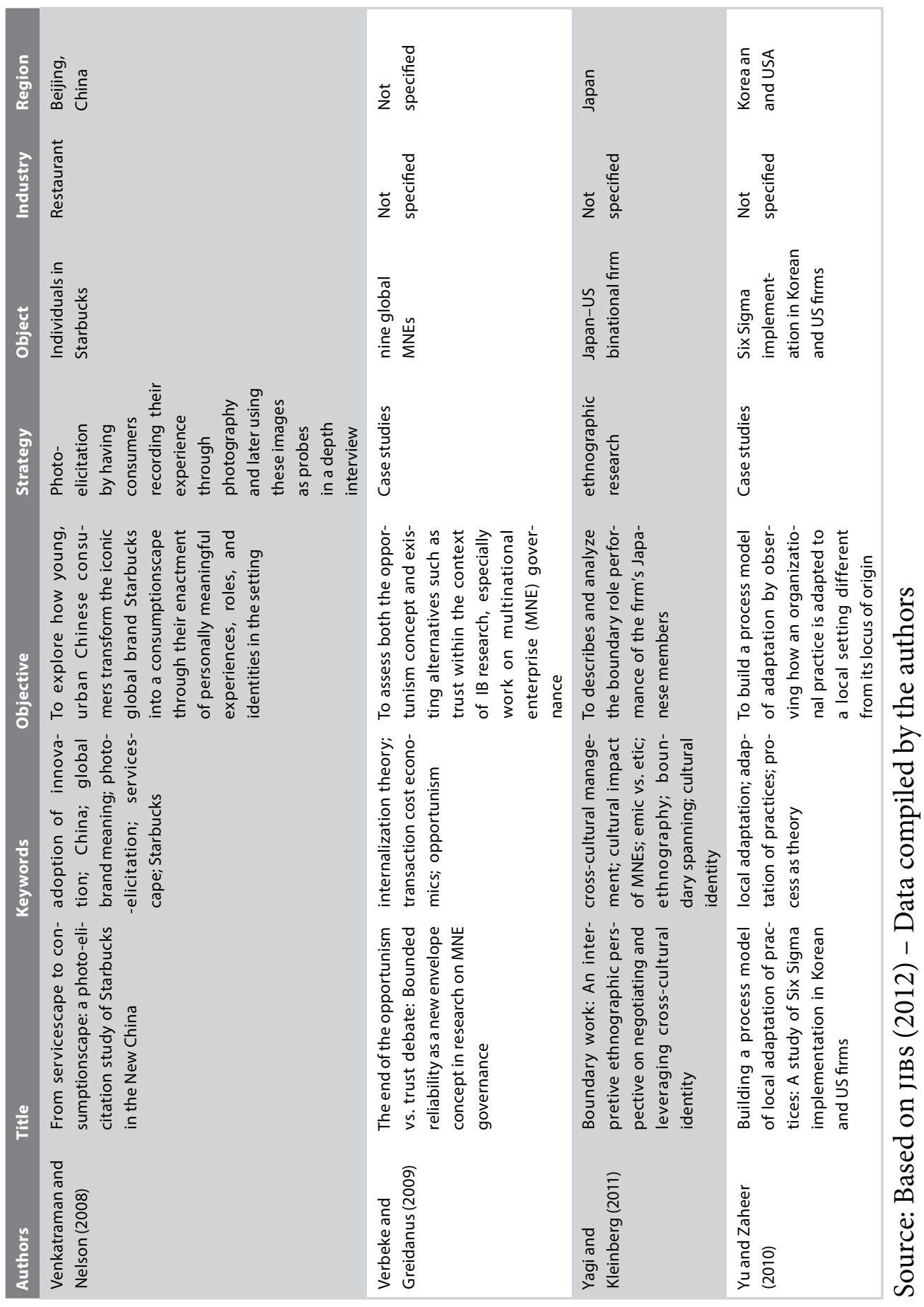




\section{RESULTS}

This study aimed to offer an overview over theoretical-empiric studies published on JiBs, since 2003 till 2012 (till November), based on abstracts, titles and keywords.

\section{STRATEGY OF INVESTIGATION}

Strategy of investigation is not an option. It depends on what the researcher need to answer. The research question is related directly to the choice of methods, and the methods section must be articulated to a particular qualitative method or combination of method to be applied (BIRKINSHAw; BRANNEN; TUNG, 2OII). Abundance of data and access to them permitted a huge expansion of quantitative research. In these twenty seven articles we found twelve case studies, three ethnographic studies, three metanalysis, three triangulations (we included quantitative methods associated to qualitative), one phenomenography study, one photo-elicitation and one experiment. Observing last three years, it's relevant that in 2010 just three qualitative studies were published on JIBS, among 62 papers (5\%). It looks like that it was the institutional attraction of JIBS raised 20 II results. After a special call of qualitative research papers, among 53 papers, nine were qualitative in $201 \mathrm{I}$ (I7\%). Nevertheless, in 2012 (Jan-Nov), just two qualitative studies were published, among 33 (6\%).

\section{OBJECT OF STUDY}

In this paper we considered object of study the level of analysis that authors appointed in their abstracts. All of them have organization as level of analysis. Even though some papers didn't declare size of companies, two groups have relevant presence: multinationals and small business. Usually, multinationals are an interesting field for research when it is necessary to make comparisons between subsidiaries. Small firms are investigated mainly in entrepreneurship issues. However differences must be related. Comparisons between distinct behaviors in different countries were also related as object of study. International operations also were studied, like 
joint ventures, alliances, merges and acquisitions. It's also relevant that individuals are often considered object of studies, coherent to qualitative study options.

\section{OBJECTIVES}

According to Eisenhardt (1989), case study research is a rich field to develop theory. Building theory in International Business involves a vast field, mixing different cultures, institutional environments, different industries, political adversities, and so on. The articles we've searched are committed to this challenge. In addition, some of them take more interpretative and inductive strategies, like ethnography. Contribution in theory is not just an idea for research, as written by Locke and Golden-biddle (1997). It must be socially accepted and recognized among researchers of organizational field. The authors aimed to connect innovation, culture strategy, conciliating to International Business research and enacting interdisciplinary as stated on JiBs policy. Furthermore, qualitative researches allow depth analysis. It's clear in Balogun, Jarzabkowski, and Vaara's (20II) objective: "to explore the subtle dynamics in the way that both headquarters and subsidiaries subjectively reconstruct their independent-interdependent relationships with each other during change". Similar happen to Moore (20II). His intention was "to analyze cross-cultural relationships in the organization, the interaction of manager and worker perspectives, and the expression of national identities within the firm as its culture is negotiated". Relationships are in the gray area for statistical studies. It supposed to be more flattering subjective strategies of investigations to evaluate this mainstream.

\section{PLACES}

Peng, Sun, Pinkham and Chen (2009) considered how important should be to have more investigation in emerging countries. Actually, last year's an important volume of research is taking place far from developed countries. Just in these twenty seven papers four refer to studies at Chinese organizations, one in East Europe (Romania) and four in Latin America (Chile, Dominican Republic, Guatemala, and Mexico). The East 
Asia is predominant. Beside China, Japan and Korea have been fields of investigation. One study was made in Sweden, one in Australia, one in Italy, and two compared US to other countries (Japan and Korea). South America and Africa are still mysterious.

\section{INDUSTRY}

Among twenty seven qualitative research abstracts, just in seven we got to identify in which industry the research was performed. Automotive industry was investigated twice, and so telecom was. Also, restaurant, winery and furniture industries were space for researchers. In qualitative studies, the context is an important subject. Unfortunately, the most of researchers didn't mention it in the abstracts, keywords or even titles.

\section{KEYWORDS}

This item refers to the section 2 . Three hundred sixty eight keywords were mentioned in 497 articles. We grouped them in 13 generic topics: culture, emerging markets, finance/performance, individuality/entrepreneurship issues, industry, innovation/ knowledge, institutions, internationalization process, interrelation issues, methodology, resources/ capabilities, strategy and theories. These topics can illustrate mainstreams for investigation that are currently published in JiBs. 


\section{FINAL CONSIDERATIONS}

Even though JiBs has been recognized as the main space for International Business Studies, editors are conscious about how important is to extend qualitative researches. According to Ellis (2010), the average effect size in international business research has been small. He considers that many authors confuse statistical with substantive significance when interpreting their research results. Hence, what we have is a lot of statistical confirmation about what we already know, endorsing the normal science predicted by Kuhn (1996). In a globalization era, even studies are becoming globalized, generalized. Comparison between different cultures by statistical methods represents risks. Cognitive perceptions of surveyed respondents may carry differences in understanding, language, even in ethics and moral that hardly could be registered by statistical methods.

This study intended to offer an overview over theoretical-empiric studies published on JiBs, since 2003 till 2012, based on keywords and abstracts. Furthermore, it was an exercise to grasp qualitative studies and objectives we were seeking as prominent in IB. The proposal was achieved in different levels: Firstly, it presented the proportion of qualitative studies over the total published on JIBS, showing that in interpretative approaches are becoming sparse. Secondly, keywords were analyzed and grouped by topics, evidencing fields which qualitative studies have been published in JiBs. Thirdly, we grouped a keyword topic analysis section presenting some representative studies, as well as some connections they have among them. Finally, we detailed and analyzed twenty seven articles in order to provide information for further research thru a main panel, comprehending the last five years (Table 2).

It's noteworthy that there are gaps to be investigated. Considering just these ten years, nothing from South America (except Chile - DEL SOL; KOGAN, 2007) and Africa were published under qualitative strategy of researching. BRICS (Brazil, Russia, India, China and South Africa) for instance was out of studies, but China (I0) and India (2). Evaluation about understanding institutional involvement in IB is indispensable to know better the 
interrelationship between countries, firms and individuals. During last decades, IB expanded as well people moved between subsidiaries. How they are dealing with it? How knowledge is flowing in different levels of analysis? How culture is related to many issues? There is an arsenal of questions to be answered and qualitative methods can be an interesting way of searching IB studies deeper.

It's necessary to clarify that we don'tintend to point this lack of investigation as some kind of rejection of interpretative papers made intentionally by editors. Better we would like to provoke reflections about the quality level of qualitative studies we are offering to academia. Producing interpretative studies doesn't mean to build data without connections to theory; as we are involved in a prevalent quantitative mindset it is severely important to be accurate in methodological steps, detailing them, checking evidences, confronting visions widely.

We consider the short period (ten years in keywords and five in abstracts) we investigated as limitation of this paper. A larger range of time could better stand for what has been published in JiBs in qualitative strategies of research. Also, it could be extended to other relevant journals, even for comparison. Checking just abstracts and keywords is also a restraint. For future investigation we suggest strengthen the scope of investigation, comparing what has been searched also in quantitative approaches. It could provide interesting confrontation and new insights in order to give possibilities of understanding who researchers are talking about, what is the object of investigation, how researches have been processed, and, mainly, if the method is adequate to the investigation proposed. The largest sample isn't always the best one. Huge sampling sometimes can be compared to a map of a lake scaled I:I without depth for understanding from where the water comes. 


\section{REFERENCES}

ANDERSON, H.; GATIGNON, E. Modes of foreign entry: a transaction cost analysis and propositions. Journal of International Business Studies, v. 17, n. 3, p.1-26, 1986.

BALOGUN, J.; JARZABKOWSKI, P.; VAARA, E. Selling, resistance and reconciliation: A critical discursive approach to subsidiary role evolution in MNEs. Journal of International Business Studies, v. 42, p.765-786, 2011

BARDIN, L. Análise de Conteúdo. Lisboa: Edições 70, 1977.

BIRKINSHAW, J.; BRANNEN, M. Y.; TUNG, R. L. From a distance and generalizable to up close and grounded: Reclaiming a place for qualitative methods in international business research. Journal of International Business Studies, v. 42, n. 5, p.573-581. 2011.

BOLINO, M. K. Expatriate assignments and intra-organizational career success: implications for individuals and organizations. Journal of International Business Studies, v. 38, p.819-835, 2007.

BRANNEN, M.Y; PETERSON, M. Merging without alienating: interventions promoting cross-cultural organizational integration and their limitations. Journal of International Business Studies, v. 40, p.468-489, 2009.

BROWN, J.R.; DEV, C.S.; ZHOU, Z. Broadening the foreign market entry mode decision: separating ownership and control. Journal of International Business Studies, v. 34, p.473-488, 2003.

BRUTON, G.D.; KHAVUL, S.; CHAVEZ, H. Microlending in emerging economies: Building a new line of inquiry from the ground up. Journal of International Business Studies, v. 42, p.718-739, 2011.

CAPAR, N.; KOTABE, M. The relationship between international diversification and performance in service firms. Journal of International Business Studies, v. 34, p.345-355, 2003.

CAPRAR, D. V. Foreign locals: A cautionary tale on the culture of MNC local employees. Journal of International Business Studies, v. 42, p.608-628, 2011.

CARRAHER, S.M.; SULLIVAN, S.E.; CROCITTO, M.M. Mentoring across global boundaries: an empirical examination of home- and host-country mentors on expatriate career outcomes. Journal of International Business Studies, v. 39, p.1310-1326, 2008.

CHEN, X.; LI, S. Cross-national differences in cooperative decision-making in mixedmotive business contexts: the mediating effect of vertical and horizontal individualism. Journal of International Business Studies, v. 36, p.622-636, 2005.

CHILD, John; CHUNG, L.; DAVIES, H. The performance of cross-border units in China: a test of natural selection, strategic choice and contingency theories. Journal of International Business Studies, v. 34, p.242-254, 2003.

CHOI, CHANG-BUM; BEAMISH, P.W. Split management control and international joint venture performance. Journal of International Business Studies, v. 35, p.201-215, 2004. 
COVIELLO, N. E. The network dynamics of international new ventures. Journal of International Business Studies, v. 37, p.713-731, 2006.

CUERVO-CAZURRA, A.; MALONEY, M.M; MANRAKHAN, S. Causes of the difficulties in internationalization. Journal of International Business Studies, v. 38, p.709-725, 2007.

DEL SOL, P.; KOGAN, J. Regional competitive advantage based on pioneering economic reforms: the case of Chilean FDI. Journal of International Business Studies, v. 38, p.901-927, 2007.

DUNNING, J. H. Toward an eclectic theory of international production - some empirical tests. Journal of International Business Studies, v. 11, n.1, p.9-31, 1980.

DUNNING, J. H. The eclectic paradigm of international production - a restatement and some possible extensions. Journal of International Business Studies, v. 19, n.1, p.1-31, 1988.

EAPEN, A. Social structure and technology spillovers from foreign to domestic firms. Journal of International Business Studies, v. 43, p.244-263, 2012.

EISENHARDT, K. M. Building Theories from Case Study Research. Academy of Management Review, v. 14, n. 4, p.532-550, 1989.

ELLIS, Paul D. International trade intermediaries and the transfer of marketing knowledge in transition economies. Journal of International Business Review, v. 19, n. 1, p.1633, 2009.

FAN, T.; PHAN, F. International new ventures: revisiting the influences behind the 'born-global' firm. Journal of International Business Studies, v. 38, p.1113-1131, 2007.

FILATOTCHEV, I.; STRANGE, R.; PIESSE, J.; LIEN, Y. FDI by firms from newly industrialised economies in emerging markets: corporate governance, entry mode and location. Journal of International Business Studies, v. 38, p.556-572, 2007.

GERTSEN, M.C.; SØDERBERG, A. Intercultural collaboration stories: On narrative inquiry and analysis as tools for research in international business. Journal of International Business Studies, v. 42, p.787-804, 2011.

GOERZEN, A.; MAKINO, S. Multinational corporation internationalization in the service sector: a study of Japanese trading companies. Journal of International Business Studies, v. 38, p.1149-1169, 2007.

GOULD, S.J.; GREIN, A.F. Think glocally, act glocally: a culture-centric comment on Leung, Bhagat, Buchan, Erez and Gibson (2005). Journal of International Business Studies, v. 40, p.237-254, 2009.

HUNG, K.H.; GU, F.F.; YIM, C.K. A social institutional approach to identifying generation cohorts in China with a comparison with American consumers. Journal of International Business Studies, v. 38, p.836-853, 2007.

HUNG, K.H.; LI, S.Y.; BELK, R.W. A social institutional approach to identifying generation cohorts in China with a comparison with American consumers. Journal of International Business Studies, v. 38, p.1034-1051, 2007. 
HUTZSCHENREUTER, T.; PEDERSEN, T.; VOLBERDA, H. W. The role of path dependency and managerial intentionality: a perspective on international business research. Journal of International Business Studies, v. 38, n. 7, p.1055-1068, 2007.

JAVIDAN, M. Core Competence : What Does it Mean in Practice ? Science, v. 31, n. 1, 1998.

JACKSON, G.; DEEG, R. Comparing capitalisms: understanding institutional diversity and its implications for international business. Journal of International Business Studies, v. 39, p.540-561, 2008.

JiBs. Journal of International Business Studies. Retrieved December 5, 2012, from: http:// www.palgrave-journals.com/jibs/index.html., 2012.

JOHANSON, J.; VAHLNE, J. E. The internationalization process of the firm - a model of knowledge development and increasing foreign markets commitments. Journal of International Business Studies, p. 23-32, 1977.

JOHANSON, J.; VAHLNE, J.E. The mechanism of internationalisation. International Marketing Review, v.7, n. 4, p.11-24, 1990.

JOHANSON, J.; VAHLNE, J. E. Business relationship learning and commitment in the internationalization process. Journal of International Entrepreneurship, v. 1, p. 83-101, 2003.

JOHANSON, J.; VAHLNE, J.E. The Uppsala internationalization process model revisited : from liability of foreignness to liability of outsidership. Journal of International Business Studies, v.40, p.1411-1431, 2009.

JOHANSON, J. A. N.; WIEDERSHEIM-PAUL, F. The Internationalization of the firm four Swedish Cases. The Journal of Management Studies, p.305-322, 1975.

JONES, M.V.; COVIELLO, N.E. Internationalisation: conceptualising an entrepreneurial process of behaviour in time. Journal of International Business Studies, v. 36, p.284-303, 2005.

JONSSON, A.; FOSS, N.J. International expansion through flexible replication: Learning from the internationalization experience of IKEA. Journal of International Business Studies, v. 42, p.1079-1102, 2011.

KHANNA, Tarun; PALEPU, K.G. Globalization and convergence in corporate governance: evidence from Infosys and the Indian software industry. Journal of International Business Studies, v. 35, p.484-507, 2004.

KHATRI, N.; TSANG, E.W.K.; BEGLEY, T.M. Cronyism: a cross-cultural analysis. Journal of International Business Studies, v. 37, p.61-75, 2006.

KNIGHT, G.; CAVUSGIL, T. Innovation, organizational capabilities, and the born-global firm, Journal of International Business Studies, v. 35, p.124-141, 2004.

KNIGHT, G.A.; KIM, D. International business competence and the contemporary firm. Journal of International Business Studies, v. 40, p. 255-273, 2009.

KUHN, Thomaz. The Structure of Scientific Revolutions. The University of Chicago Press, 1996. 
KUMAR, K.; FENEMA, P.C.; GLINOV, M.A. Offshoring and the global distribution of work: Implications for task interdependence theory and practice. Journal of International Business Studies, v.40, p.642-667, 2009.

LAMB, P., SANDBERG, J., LIESCH, P. W. Small firm internationalisation unveiled through phenomenography. Journal of International Business Studies, v. 42, p.672-693, 2011.

LAU, V.P.; SHAFFER, M.A.; AU, K. Entrepreneurial career success from a Chinese perspective: conceptualization, operationalization, and validation. Journal of International Business Studies, v. 38, p.126-146, 2007.

LAZAROVA, M.B.; CERDIN, J. Revisiting repatriation concerns: organizational support versus career and contextual influences. Journal of International Business Studies, v. 38, p.404-429, 2007.

LEE, K.; YANG, G.; GRAHAM, J.L. Tension and trust in international business negotiations: American executives negotiating with Chinese executives. Journal of International Business Studies, v. 37, p.623-641, 2006.

LOCKE, K.; GOLDEN-BIDDLE, K. Constructing opportunities for contribution : Structuring intertextual cohere. Academy of Management Journal, v. 40, n. 5, p.1023$1062,1997$.

LONDON, T.; HART, S.L. Reinventing strategies for emerging markets: beyond the transnational model. Journal of International Business Studies, v. 35, p.350-370, 2004.

MARTIN, X.; SALOMON, R. Knowledge transfer capacity and its implications for the theory of the multinational corporation. Journal of International Business Studies, v. 34, p.356-373, 2003.

MEYER, C.B.; ALTENBORG, E. Incompatible strategies in international mergers: the failed merger between Telia and Telenor. Journal of International Business Studies, v. 39, p.508-525, 2008.

MEYER, K. E.; PENG, M. W. Probing theoretically into Central and Eastern Europe: transactions, resources, and institutions. Journal of International Business Studies, v. 36, n. 6, p.600-621, 2005.

MININ, A. DI; BIANCHI, M. Safe nests in global nets: Internationalization and appropriability of R\&D in wireless telecom. Journal of International Business Studies, v. 42, p.910-934, 2011.

MOORE, F. Holistic ethnography: Studying the impact of multiple national identities on post-acquisition organizations. Journal of International Business Studies, v. 42, p.654-671, 2011.

NORTH, D. C. Institutions, Institutional Change, and Economic Performance. Cambridge: Cambridge University Press, 1990.

ORR, R.J.; SCOTT, W.R. Institutional exceptions on global projects: a process model. Journal of International Business Studies, v. 39, p.562-588, 2008. 
PAJUNEN, K. Institutions and inflows of foreign direct investment: a fuzzy-set analysis. Journal of International Business Studies, v. 39, p.652-669, 2008.

PENG, M.W. The resource-based view and international business. Journal of Management, v. 27, p.803-829, 2001.

PENG, M. W.; SUN, P.; PINKHAM, B.; CHEN, X . The Institution-Based View as a Third Leg for a Strategy Tripod. Academy of Management Perspectives, v.23, n.3, p.63-81, 2009.

PENG, M. W.; WANG, D. Y. L.; JIANG, Y. An institution-based view of international business strategy: a focus on emerging economies. Journal of International Business Studies, v. 39, n.5, p.920-936, 2008.

RICART, J.E.; ENRIGHT, M.; GHEMAWAT, P.; HART, S.L.; KHANNA, T. New frontiers in international strategy. Journal of International Business Studies, v. 35, p.175-200, 2004.

SHAPIRO, J.M.; OZANNE, J.L.; SAATICIOGLU, B. An interpretive examination of the development of cultural sensitivity in international business. Journal of International Business Studies, v. 29, p.71-87, 2008.

SIEGEL, J. Is there a better commitment mechanism than cross-listings for emergingeconomy firms? Evidence from Mexico. Journal of International Business Studies, v. 40, p.1171-1191, 2009.

SIRMON, D.G.; LANE, P.J. A model of cultural differences and international alliance performance. Journal of International Business Studies, v. 35, p. 306-319, 2004.

SPENCER, J. W. Global gatekeeping, representation, and network structure: a longitudinal analysis of regional and global knowledge-diffusion networks. Journal of International Business Studies, v. 34, p.428-442, 2003.

SUN, P.; MELLAHI, K.; THUN, E. The dynamic value of MNE political embeddedness: The case of the Chinese automobile industry. Journal of International Business Studies, v. 41, p.1161-1182, 2010.

TEEGEN, H.; DOH, J.P.; VACHANI, S. The importance of nongovernmental organizations (NGOs) in global governance and value creation: an international business research agenda. Journal of International Business Studies, v. 35, p.463-483, 2004.

TIPPMANN, E.; SCOTT, P.S.; MANGEMATIN, V. Problem solving in MNCs: How local and global solutions are (and are not) created. Journal of International Business Studies, v. 43, p.746-771, 2012.

TSUI-AUCH, L.S.; MOLLERING, Guido, Wary managers: Unfavorable environments, perceived vulnerability, and the development of trust in foreign enterprises in China. Journal of International Business Studies, v. 41, p.1016-1035, 2010.

VENKATRAMAN, M.; NELSON, T. From servicescape to consumptionscape: a photoelicitation study of Starbucks in the New China. Journal of International Business Studies, v. 39, p.1010-1026, 2008.

VERBEKE, A.; GREIDANUS, N.S. The end of the opportunism vs trust debate: Bounded reliability as a new envelope concept in research on MNE governance. Journal of 
International Business Studies, v. 40, p.1471-1495, 2009.

VERLEGH, P. W. J. Home country bias in product evaluation: the complementary roles of economic and socio-psychological motives. Journal of International Business Studies, v. 38, p.361-373, 2007.

VERNON, R. International investment and international trade in the product cycle. Quaterly Journal of Economics, p.190-207, 1966.

VERNON, R. The product cycle hypothesis in a new international environment. Oxford Bulletin of Economics \& Statistics, v. 54, n. 4, p.255-268, 1979.

WANG, C.; HONG, J.; KAFOUROS, M.; WRIGHT, M. Exploring the role of government involvement in outward FDI from emerging economies. Journal of International Business Studies, v. 43, p.655-676, 2012.

WEB OF KNOWLEDGE. Web of Knowledge. Retrieved December 3, 2012, from: http:// apps.webofknowledge.com.

WEINER, R. J. Speculation in international crises: report from the Gulf. Journal of International Business Studies, v. 36, p.576-587, 2005.

YAGI, N.; KLEINBERG, J. Boundary work: An interpretive ethnographic perspective on negotiating and leveraging cross-cultural identity. Journal of International Business Studies, v. 42 , p. $629-653 ., 2011$.

YIU, D.W.; LAU, C.M.; BRUTON, G.D. International venturing by emerging economy firms: the effects of firm capabilities, home country networks, and corporate entrepreneurship. Journal of International Business Studies, v. 38, p.519-540, 2007.

YU, J.; ZAHEER, S. Building a process model of local adaptation of practices: A study of Six Sigma implementation in Korean and US firms. Journal of International Business Studies, v. 41, p.475-499, 2010.

This article was produced under financing sponsorship of CAPES (Coordenação de Aperfeiçoamento de Pessoal de Nível Superior). 


\section{DADOS DOS AUTORES}

\section{SÍLVIO LUÍS DE VASCONCELLOS ${ }^{\star}$ silvio.v@ienh.com.br} Doutorando em Administração pela UNISINOS

Instituição de vinculação: Instituição Evangélica de Novo Hamburgo

Novo Hamburgo/RS - Brasil

Áreas de interesse em pesquisa: Negócios internacionais.

${ }^{\star}$ Rua Frederico Mentz, 526 Hamburgo Velho Novo Hamburgo/RS 93525-360

\section{IVAN LAPUENTE GARRIDO igarrido@unisinos.br}

\section{Doutor em Administração pela UFRGS}

Instituição de vinculação: Universidade do Vale do Rio dos Sinos

São Leopoldo/RS - Brasil

Áreas de interesse em pesquisa: Negócios internacionais.

\section{JEFFERSON MARLON MONTICELLI jeffmarlon@hotmail.com}

Mestrando em Administração pela UNISINOS

Instituição de vinculação: Universidade do Vale do Rio dos Sinos

São Leopoldo/RS - Brasil

Áreas de interesse em pesquisa: Negócios internacionais.

YEDA SWIRSKI DE SOUZA yedasou@unisinos.br Doutora em Psicologia pela PUC/RS

Instituição de vinculação: Universidade do Vale do Rio dos Sinos

São Leopoldo/RS - Brasil

Áreas de interesse em pesquisa: Empreendedorismo internacional e sobre o desenvolvimento de capacidades de empresas para negócios internacionais.

CYNTIA VILASBOAS CALIXTO cyntia.calixto@gvmail.br Doutoranda em Administração de Empresas pela FGV/EAESP Instituição de vinculação: Fundação Getúlio Vargas FGV/EAESP São Leopoldo/RS - Brasil

Áreas de interesse em pesquisa: Negócios internacionais e estratégia empresarial. 